\title{
The Countermeasure of Forest Destruction Through Communities Based on Land Utilization Empowerment in Gembong Sub-District, Pati Regency, Central Java Province
}

\author{
Moh. Solehatul Mustofa ${ }^{1}$ \\ \{ $\underline{\text { mustofa@mail.unnes.ac.id }}{ }^{1}$ \} \\ ${ }^{1}$ Universitas Negeri Semarang, Indonesia
}

\begin{abstract}
Forest destruction is increasing in various areas in Indonesia. If the countermeasure is not carried out, the forest destruction will get worse. One of the perpetrators of forest destruction is the community in the forest village (Desa Hutan), and the network is the capital owners and industrial businesses that require forest products. The countermeasure will hardly happen without community involvement. Based on the description, there are some problems as follows, how is the effectiveness of social involvement in overcoming the forest destruction problem through the use of land under the stand (tegakan); how to strive the social behavior to respond the utilization lands programs under the stand (tegakan). The method used in this research is the qualitative method. The research locations were Semirejo Village and Klakah Kasihan Village, Gembong Sub-District, Pati Regency. The results of this study indicate that based on Semirejo and Klakah Kasihan Village cases, it is known that the empowerment of the community through land use of stand(tegakan) can effectively support the countermeasures of forest destruction. The community and Indonesian Forest Company (Perhutani) provide mutual benefits. The community earns income from utilizing the land under the stands, Indonesian Forest Company (Perhutani) gets benefits that they no longer damage the forest, actively protect the forests in their area from the residents' disturbance of surrounding communities and other regions. The way to overcome forest damage through community involvement by using a technical and institutional approach that is mutually beneficial
\end{abstract}

Keywords: Countermeasure of Forest Destruction, Empowerment, Land Use Under Stand

\section{Introduction}

Forest destruction is a problem in various countries including Indonesia. Forest destruction has become a concern of the world and various countries, although forest destruction continues to occur. It can be seen by the fact that more damaged forests, the change of forest land functions, as well as the reduction of the forest area. In 2013, Indonesia lost \pm 1.1 million hectares of natural forest. The number of degraded forests can be seen in various places so that it becomes barren land, although it has not been used yet by others. This cannot be tolerated because forests have very important functions for humanity and the preservation of the earth. Forests as the main oxygen producer and as the lungs of the world are very much needed by humans. 
Forests are also a breeding ground for diverse animals, a place to conserve water sources and to maintain the balance for organisms on earth in a life cycle. Therefore, the existence of the forest must be preserved. There are several factors cause forest destruction, one of them is deforestation. Deforestation and forest degradation in Indonesia are caused by fires and encroachment of illegal logging and illegal trading, forest areas conversion, the use of forest areas outside the forestry sector, and harvesting. Moreover, forest destruction becomes greater because of human behavior. The impact of human behavior that causes forest destruction is the activity of the surrounding population [1]. The behavior of the surrounding population that affects forest destruction is caused by poverty [2].

It has been realized that there are a role and influence of the surrounding population on forest destruction. Therefore, various efforts have been done to tackle forest destruction based on community empowerment. One of the empowerment ways is the use of community-based forest land for crops that do not cause forest destruction, including the use of land under the stand. This study discusses forest destruction and several efforts to overcome it through community empowerment around the forest by using land under the stands. The problems discussed were: how effective is the community involvement in tackling the problem of forest destruction through land use under the stands (tegakan); how to strive for community behavior to respond to the utilization lands programs under the stand (tegakan). The utilization lands programs under stand

\section{Literature Review}

\subsection{The Poverty of Forest Village Community}

Communities that live around forests generally depend on forest products. They are farmers working on forest land, laborers in Indonesian Forest Company (Perhutani) or small land farmers with secondary jobs [1], [3], [4]. Forest villages (Desa Hutan) are generally far from the city and relatively isolated, difficult roads to pass, underdeveloped transportation, making some difficulties for residents to access education and economic resources from the city. This condition of infrastructure and human resources makes it hard to develop their economic life [5], [6], [7]. By these conditions, the forest village (Desa Hutan) community becomes more dependent on life than dependent on a forest-based economy. One of those findings was working on Indonesia Forest Company's (Perhutani) forest land, using grass for their livestock, hunting animals, cutting down forests or destroying forest land to make sand, stone quarry, and clearing forest land with very little economic results and difficult to improve their living standards.

Poverty among forest villagers who do not have their own agricultural land and depend on forest land causes the community in destroying the forest. The policies that have not raised the fate of forest village communities trigger them to destroy forests. On the other hand, that behavior is also supported by employers who utilize the land around the forest. Most of the community cut the lodge down and sell it to the urban traders.

\subsection{The Countermeasure of Forest Destruction}

Forest destruction continuously happens in the form of logging by several people around the forest which belongs to theft or done by companies for the sake of company development. A large number of people who commit theft causes the forest to become bare or open. Theft is 
done at a time when Perhutani officials tend not to be on guard. Some difficulties faced by Indonesia Forest Company (Perhutani) when facing more and more, forest village farmers are destroying forests causing tension in Indonesia Forest Company (Perhutani) relations with forest villagers. Destruction is mainly caused by pressure from the surrounding community which is related to poverty, thus overcoming it by overcoming the problem of poverty [1], [8], [9], [10]. To prevent forest destruction is to empower the economic life of forest village communities [5], [11], [12]. Based on this concept, there are several ways can be used to empower the poor community around the forest to make them able to live independently, following the advice of [13], [14]. The possible ways that can be done are by adding skills to increase the productivity of their work, so they will not destroy the forest anymore. Moreover, the surrounding residents not only take the role of reforestation agents but also responsible for planting on land that will be used for agriculture and utilizing grass for their livestock as well as providing capital assistance for economic cooperation with forest village communities. However, skill assistance for their independence through education and training is also absolutely needed.

One of the forest management that involves the community on using the planting pattern is how to manage the forest by applying a mixed planting pattern between the types of forestry plants and the crops. Indonesia Forest Company has been involved in intercropping, cooperation with communities around the forest through forest land contracts as an embodiment of the agroforestry implementation (Banowati, 2011). The surrounding residents are not only given a role in reforesting, planting the land that is used for agriculture, and utilizing grass for their livestock. Moreover, capital assistance is provided for economic cooperation business among the forest village communities. In addition, they are trained to assist their independence through education and training.

\section{Research Method}

The study was conducted by a descriptive qualitative method. This research used an objective observation method and interviews for the data collection. The research team observed Indonesian Forest Company's (Perhutani) land in several areas especially the area near these two villages in the Gembong sub-district, Semirejo and Klakah Kasihan Village. Besides, the researcher interviewed $L M D H$ administrators, farmer groups and sharecroppers, called pesanggem. The are several ways to meet farmers not only at home but also on the forest land that they worked on (in local terms called borgan land). Moreover, information obtained from pesanggem was confirmed by information from other pesanggem farmers and the management of the Farmer Group and the $L M D H$ management.

To strengthen the truth of the collected data, the researcher also held a Focus Group Discussion (FGD) represented by each of the elements associated with involving pesanggem farmers in utilizing Indonesia Forest Company (Perhutani) land. The member of Perhutani, village officials, and pesanggem farmers from Perhutani lands and $L M D H$ administrators were attending the Focus Group Discussion(FGD). The collected data is processed and analyzed by classifying, interpreting, and describing it into research reports and articles 


\section{Result and Discussion}

\subsection{Economic Condition of Community in Forest Village (Desa Hutan)}

The subjects of this research are the forest area near Semirejo and Klakah Kasihan Village in Gembong Sub-District, Pati regency. Like any other Forest Villages mentioned in the literature review, there are several poor people at Semirejo and Klakah Kasihan Village. Therefore, the people in Forest Village which became the subject of this research belong to the poor people at Semirejo Village as well as Klakah Kasihan Village. The economic condition of poor people generally works as farm laborers, narrow land farmers, breeders, service helpers, and forest products, for example utilizing tree branches for firewood. The income of poor people is insufficient to fulfill the necessities of their lives. Farming industries of poor people in a land less than 0,25 ha certainly not enough to fulfill their needs. Moreover, the harvest of rice or supplementary crops, which they usually plant, are inconsistent because their farm belongs to the rainfed category. The farm laborers have it harder because they rely on another person farming industries, which their salary comes from helping to farm, maintaining the plants, and helping the harvest. In addition, their salary is even smaller. The product from small-scaled breeding industries cannot fulfill their family's necessities.

Family in Forest Village community must fulfill their primary needs such as foods, clothes, and homes, even more, they have social and health needs. No matter how hard they simplify their needs of foods, clothes, and homes, it is still difficult to fulfill. They worked not only to satisfy their own needs, but their family needs also have to be fulfilled, especially kids and parents who cannot work anymore. They also have to send their children to school, at least until they graduated from elementary school or high school. Helping the funding of sick family members, able to donate in village events, holding religion ceremonies, and any other social event is also their outcome. Not only that, they sometimes have to pay their debt. The complex life necessities and must be satisfied is difficult for them to fulfill from their own business. This condition makes them exploit the forest to fulfill their needs and render the forest damaged.

Forest Village community poverty, which generally poor education, poor skills and narrow-minded are causing difficulties to get out of their low income and their poverty. Several attempts had been made from government or private party to help them. Indonesia Forest Company (Perhutani) already gives them the help they need but in the form of consumptive assistance. Food subsidies, scholarships to help kids get into school, also cheaper hospital costs as well as social compensation are frequently given for the communities. These kinds of help are very useful, yet temporary because it is consumed and quickly exhausted. All of the helps cannot solve the problem of fulfilling other needs which tend to be independent. With all the help they got all this time, the communities depended on the help of others too much.

\subsection{The State of the Forest}

Forests area near Semirejo and Klakah Kasihan Village in Gembong are different in terms of the categories. On Samirejo Village, it falls under the production forest category in the form of the teak forest. This forest is located in a relatively flat and similar area. The owner of the forest is Indonesia Forest Company or Perhutani, Forest Management Unit Pati, a StateOwned Enterprise. The use of Perhutani land by farmers is only temporary as a usufruct on Perhutani land on land determined by the place and time. 
In Klakah Kasihan Village, it falls under the protected forest category which is located on the slopes of Volkan Muria, so that the slope is more than $35^{\circ}$ and prone to landslides. The plant in a protected forest is not similar tree plants which cultivated to get the wood, but rather heterogeneous plantations with coffee plants (coffea) as a fence. The preferred plants are plantation crops that will not be cut to get the wood. Klakah Kasihan protected forest manifested as a fruit plant and it grows naturally. Forested types of fruit plants include durian (durio zibethinus), avocado (persea americana), and randu (ceiba pentranda). Because this is a protected forest, this forest will not be treated as a production forest like a forest Semirejo Village. The land utilization map can be seen as follows:

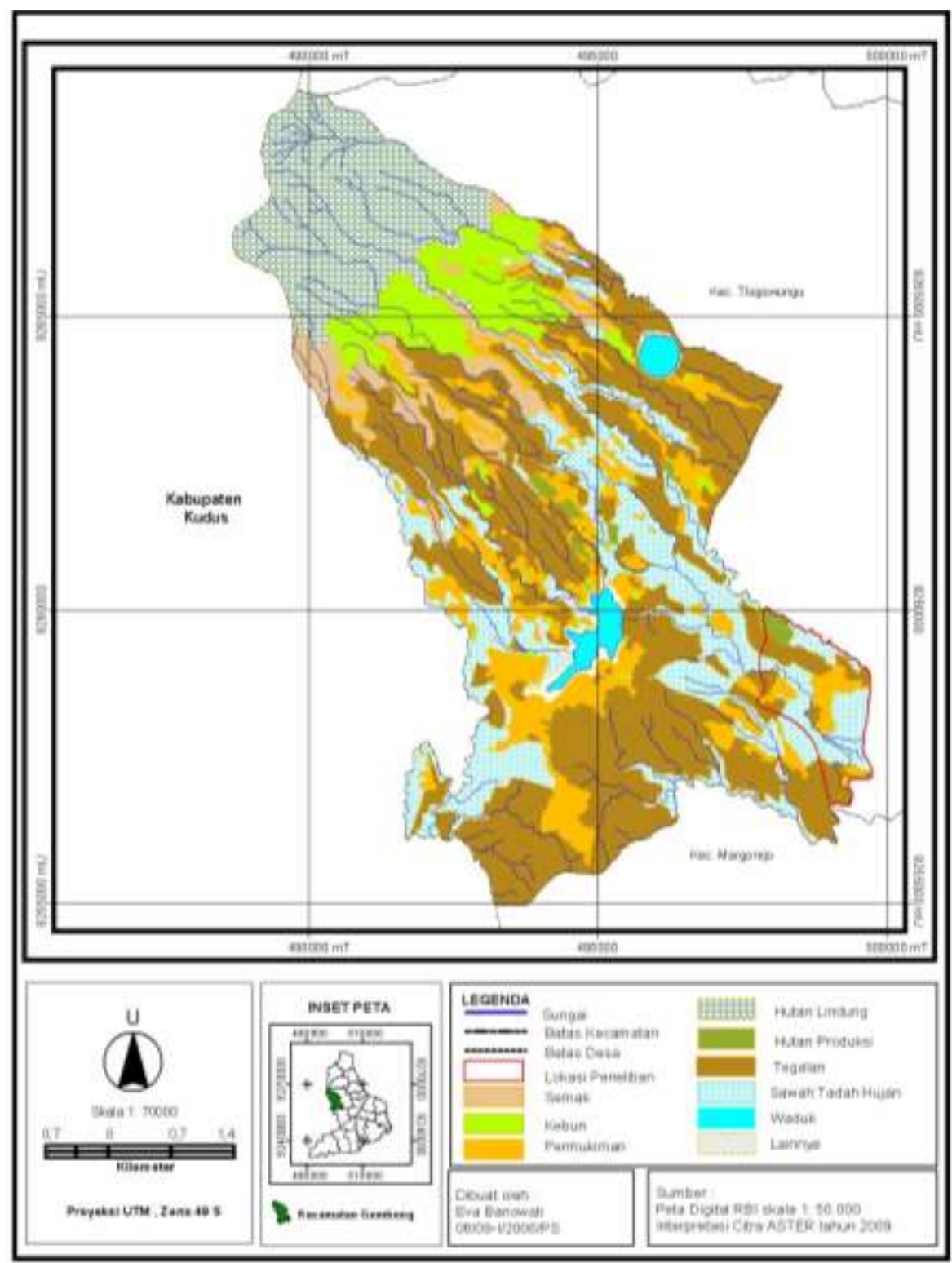


Source: Banowati, 2011.

Picture 1. The Land Utilization Map of Gembong Sub-District

There are different treatments toward production and protection forests. Production forests are regularly cut down while protection forests are not cut down. There is a time gap for the reforestation, starting from both the logging process of the production forest by Perhutani and the destruction caused by forest village farmers. It takes about 5 years for newly planted trees to grow. In this reforested production forest, Perhutani allows the forest village farmers to plant short-term crops such as rice and secondary crops. The forest village farmers' involvement is carried out to involve farmers in maintaining forest security by empowering forest village communities.

In its development, the forest near the two villages mentioned above has been destructed by farmers. The destruction caused by the worst looting is the transition of the government regime from the new order era or ORBA period to the reformation order around 1998 to 2000. There were many areas of illegal logging that destroyed forest areas. Indonesia Forest Company has gradually carried out several efforts for reforestation since 2000 . The plants that are allowed to grow are cardamom (Amomum compactum) and coffee (coffea).

\subsection{How to Involve Farmers}

Forest devastation is carried out by the poor community in the forest village so that it can be overcome then made it empower them. Economic empowerment is carried out by various parties concerned primarily the government, Indonesia Forest Company (Perhutani), private companies and other components. Empowerment in this connection is making the community able to have independent economic, by no longer relying on aid or destroying Indonesia Forest Company (Perhutani) forests or demanding from Indonesia Forest Company (Perhutani) to give forest management rights again without any time limit. The effort currently carried out by Indonesia Forest Company (Perhutani) is to provide guidance for forest village communities in collaboration with the district government to the village government. Indonesia Forest Company (Perhutani) helps farmers by giving them the right to use the land to plant certain types of plants that are temporary. Specific plant species mentioned are types of annual shrubs such as rice and secondary crops among relatively young teak forest trees which are production forests near Semirejo Village and plants with strong roots in protected forests. The economic empowerment efforts that have been carried out by granting planting rights are often called Land Utilization Under Standards (PLDT) [15] whose form of activity is to provide opportunities to plant certain crops under forest trees belonging to Indonesia Forest Company (Perhutani).

Community involvement in maintaining forest sustainability is done through a pattern of mutual benefit cooperation. The community involvement was carried out using a technical and institutional approach. The technical approach is related to the determination of land that can be cleared and utilized by forest village farmers. The determination includes the location and area as well as how to control land rights along with their rights and obligations. Among the agreements between Indonesia Forest Company (Perhutani) and farmers who have been running are open/ deforested land before planting the Indonesia Forest Company (Perhutani) can be used for agriculture by farmers. In Semirejo, the plants that can be planted are different from those in Klakah Kasihan Village. Indonesia Forest Company (Perhutani) land in Semirejo that is intended for farmers can only be planted with shrubs, such as rice and 
secondary crops. Plants that are not permitted are cassava plants such as cassava and sweet potato (ipomoae batatas) because they are understood to reduce soil fertility. Perhutani land in Klakah Kasihan which is intended for farmers can only be planted with strong rooted trees that can help maintain high slope lands such as coffee and kapulogo. Plants that are not allowed are grains and secondary crops because they are understood to be harmful to landslides.

Institutional steps are the formation of farmer group organizations and Forest Village Community Institutions $(L M D H)$. The referred farmer group is a farmer group consisting of farmers who utilize Perhutani's land. These farmer groups are formed so that farmers do not fight over land and can work together to maintain the preservation and security of forests. $L M D H$ is an institution where consultative representatives of farmer groups, representatives of Perhutani and the government in discussing problems that may and occur with a deliberative approach. This institution is a liaison between farmers and the Indonesia Forest Company (Perhutani). Besides, it makes it easier for farmer groups and LMDH to establish relations and coordination with Indonesia Forest Company (Perhutani) and the Village Government. Thus the organizational step is a communication channel between farmers and the government and Indonesia Forest Company (Perhutani) to be effective in carrying out the function of preserving the forest and empowering the economy of forest village farmers.

The involvement of farmers utilizing land by Indonesia Forest Company (Perhutani) shows the active response of farmers utilizing forest land for agriculture. Farmers who work the land are also active in taking part in preserving and protecting the forest. Teak forests that are prone to damage by community members are secured by forest village farmers groups. To ensure that the forest is also safe from the behavior of the farmer group members, the farmer group and $L M D H$ help supervise the Indonesia Forest Company (Perhutani) forest farmers' farmland. In the Perhutani area near Semirejo Village and on protected forest land near Klakah Kasihan Village the act of forest destruction since the involvement of farmers utilizing Indonesia Forest Company (Perhutani) land has decreased and has not even happened again. The main stands or trees in the Klakah Kasihan protected the forest in the form of fruit plants and productive gardens such as durian, avocado, and palm trees cause the community to choose to protect these plants while utilizing under the stands for coffee and kapulogo. Indonesia Forest Company(Perhutani) prioritizes green forests for nature conservation and farmers maintain their sustainability to get coffee and other crops that are permitted by Indonesia Forest Company (Perhutani). Cooperation between Indonesia Forest Company (Perhutani) and farmers supported by the institutional approach of farmers' groups and $L M D H$ in production forests and protected forests can realize an effort to conserve forests from cases of disturbance or pressure by villagers in forest areas.

There are several ways of empowering poor people in forest villages that have not been implemented, such as increasing forest village communities' competence in fields that do not have the dependency of utilizing wood from the forest. For example the animal husbandry and crafts marketing. Improving the skills related to animal husbandry and crafts marketing is needed so that forest village communities can have an independent economy and not dependent on the forest.

\section{Conclusion}

The results of this study indicate that based on cases in Semirejo and Kasihan Village, Gembong Sub-district, it is known that: 
a. Empowerment of the poor through the use of land under the stands (PLDT) can support the success of efforts to tackle forest damage. Through this empowerment effort, the people in the forest village and Indonesia Forest Company (Perhutani) share the same benefit. Although the effort of empowerment by Indonesia Forest Company (Perhutani) has not yet reached the direction of the independent economic, it has been able to increase income for the consumption needs of the poor. The benefits received by the community are obtaining income from utilizing the land under the stand, while the benefits of the Perhutani, farmers no longer damage the forest, actively protecting the forests in their area from the disturbance of residents from their communities and other regions.

b. The way to deal with forest destruction through community involvement in Semirejo and Klakah Kasihan village is to use technical and institutional measures that are mutually beneficial.

c. The way that has not been done in community empowerment is increasing the skills related to another field except depending on forest products.

\section{References}

[1] I. and I. A. Saputra, "Pengaruh Aktivitas Penduduk Terhadap Kerusakan Hutan Mangrove di Desa Lalombi Kecamatan Banawa Selatan,” J. Geotadulako, vol. 3, no. 6, 2015.

[2] M. S. Mustofa, "Perilaku masyarakat desa hutan dalam memanfaatkan lahan di bawah tegakan,” Komunitas Int. J. Indones. Soc. Cult., vol. 3, no. 1, 2011.

[3] I. P. G. ARDHANA, "Kajian Kerusakan Sumberdaya Hutan Akibat Kegiatan Pertambangan," ECOTROPHIC J. Ilmu Lingkung. (Journal Environ. Sci., vol. 6, no. 2, pp. 87-93, 2012.

[4] and A. C. I. M. F. Barri, A. A. Setiawan, A. R. Oktaviani, A. P. Prayoga, Deforestasi Tanpa Henti "Potret Deforestasi di Sumatera Utara, Kalimantan Timur dan Maluku Utara. Bogor: Forest Watch Indonesia, 2018.

[5] S. N. Qodriyatun, Pengentasan Kemiskinan Masyarakat Sekitar Hutan Konservasi: Studi Pemberdayaan Masyarakat Melalui Model Desa Konservasi. Jakarta: P3DI Setjen DPR RI and Azza Grafika, 2013.

[6] W. R. Annisa and S. Zunariyah, "PERUBAHAN POLA PENGELOLAAN HUTAN OLEH MASYARAKAT DI DESA KALIGUNTING (Studi Kasus PHBM di Desa Kaligunting, Kecamatan Mejayan, Kabupaten Madiun, Jawa Timur)," J. Dev. Soc. Chang., vol. 1, no. 1, pp. 76-86.

[7] G. Senoaji, "Kondisi sosial ekonomi masyarakat sekitar hutan lindung bukit daun di Bengkulu," Sosiohumaniora, vol. 13, no. 1, p. 1, 2011.

[8] S. Soenarno, W. Endom, and S. Bustomi, "Kerusakan Tegakan Tinggal Akibat Pemanenan Kayu pada Hutan Tropis Berbukit di Kalimantan Tengah,” J. Penelit. Has. Hutan, vol. 35, no. 4, pp. 273-288, 2017.

[9] B. Siliwangi, "Perusakan Lingkungan Akibat Alih Fungsi Kawasan Hutan di Hulu Sungai Citarum Menjadi Kawasan Pertanian Dihubungkan dengan Undang-undang Nomor 32 Tahun 2009 Tentang Perlindungan dan Pengelolaan Lingkungan Hidup," J. Wawasan Yuridika, vol. 30, no. 1, pp. 75-96, 2015.

[10] H. Purwandari, "Respon Petani Atas Kemiskinan Struktural (Kasus Desa Perkebunan dan Desa Hutan)," JSEP (Journal Soc. Agric. Econ., vol. 5, no. 2, pp. 24-37, 2011.

[11] E. Rositah, "Kemiskinan masyarakat desa sekitar hutan dan penanggulangannya: studi kasus di Kabupaten Malinau," CIFOR, Bogor, Indonesia, 2005. 
[12] G. B. Aji, J. Suryanto, R. Yulianti, A. Wirati, A. Y. Abdurrahim, and T. I. Miranda, "Strategi pengurangan kemiskinan di desa-desa sekitar hutan: Pengembangan model PHBM dan HKm [Poverty reduction strategy for forest villages: The development of PHBM and HKm model](research report)," Pus. Penelit. Kependud. Lemb. Ilmu Pengetah. Indones. Jakarta Selatan, vol. 40, 2013.

[13] L. B. Cattaneo and A. R. Chapman, "The process of empowerment: a model for use in research and practice.," Am. Psychol., vol. 65, no. 7, p. 646, 2010.

[14] K. Anderson, R. Stringer, and T. Feridhanusetyawan, Indonesia in a reforming world economy: Effects on agriculture, trade and the environment. University of Adelaide Press, 2009.

[15] E. Banowati and S. D. W. Prajanti, "Developing the under stand cropping system (PLDT) for sustainable livelihood," Manag. Environ. Qual. An Int. J., vol. 28, no. 5, pp. 769-782, 2017. 